\title{
PARADIGMS FOR SUBDURAL GRIDS' IMPLANTATION IN PATIENTS WITH REFRACTORY EPILEPSY
}

\author{
ARTHUR CUKIERT, ALCIONE SOUSA, ELCIO MACHADO, JOSE AUGUSTO BURATINI, \\ JOAQUIM VIEIRA, VIVIANE FERREIRA, CASSIO FORSTER, MEIRE ARGENTONI, LEILA FRAYMAN
}

\begin{abstract}
Rationale: The need for invasive monitoring in patients with refractory epilepsy has been greatly reduced by the introduction of new technologies such as PET, SPECT and MRI in the clinical practice. On the other hand, 10 to $30 \%$ of the patients with refractory epilepsy have non-localizatory non-invasive preoperative work-up results. This paper reports on the paradigms for subdural electrodes implantation in patients with different refractory epileptic syndromes. Methods: Twenty-nine adult refractory epileptic patients were studied. Patients were divided into five different epileptic syndromes that represented the majority of the patients who needed invasive recordings: bitemporal (Group I; $n=16$ ), bi-frontal-mesial (Group II, $n=5$ ), hemispheric (Group III; $n=2$ ), anterior quadrant (Group IV; $\mathrm{n}=3$ ) and posterior quadrant (Group V; $\mathrm{n}=3$ ). All of them were submitted to extensive subdural electrodes' implantation (from 64 to 160 contacts) covering all the cortical surface potentially involved in epileptogenesis under general anesthesia. Results: All patients tolerated well the procedure. There was no sign or symptom of intracranial hypertension except for headache in 22 patients. In all except one Group II patient, prolonged electrocorticographic monitoring using the described subdural cortical coverage patterns was able to define a focal area amenable for resection. In all Groups II-V patients cortical stimulation was able to adequately map the rolandic and speach areas as necessary. Conclusion: Despite recent technological advances invasive neurophysiological studies are still necessary in some patients with refractory epilepsy. The standardization of the paradigms for subdural implantation coupled to the study of homogeneous patients' populations as defined by MRI will certainly lead to a better understanding of the pathophysiology involved in such cases and an improved surgical outcome.
\end{abstract}

KEY WORDS: epilepsy, surgery, subdural electrodes, outcome, standards.

\section{Paradigmas para implante de placas subdurais em pacientes com epilepsia refratária}

RESUMO - Introdução: O advento de novas tecnologias de imagem tais como o PET, SPECT e RM diminuíram em muito a necessidade da utilização de eletrodos invasivos na investigação pré-operatória de pacientes epilépticos. No entanto, 10 a $30 \%$ dos pacientes com epilepsias refratárias ainda possuem investigação não-invasiva inconclusiva. Este estudo relata nossos paradigmas para o implante de eletrodos subdurais nesta população de epilépticos refratários. Métodos: Vinte e nove pacientes portadores de epilepsias refratárias foram estudados. Eles foram divididos em 5 grupos de síndromes epilépticas que incluíam a maioria dos pacientes submetidos a implantes: bitemporais (grupo I; $n=16$ ), bifrontomesiais (grupo II; $n=5$ ), hemisféricos (grupo III; $n=2$ ), quadrante anterior (grupo IV; $n=3$ ) e quadrante posterior (grupo V; $n=3$ ). Todos foram submetidos a extensos implantes subdurais (de 64 a 160 contatos) cobrindo todo o córtex potencialmente epileptogênico, sob anestesia geral. Resultados: Todos pacientes toleraram bem o procedimento. Vinte e dois pacientes referiram cefaléia. Não houve outro sinal ou sintoma sugestivo de hipertensão intracraniana. Com exceção de um paciente do grupo II, a monitorização eletrocorticográfica crônica foi capaz de definir uma área focal própria para a ressecção cortical. A estimulação cortical foi capaz de mapear as áreas eloquentes necessárias em todos os pacientes dos grupos II a V. Conclusão: Alguns pacientes com epilepsia refratária ainda necessitam de avaliação invasiva apesar dos avanços nos métodos diagnósticos pré-operatórios. A padronização dos paradigmas para implante subdural destes pacientes bem como o estudo de populações homogêneas de pacientes definidas por RM levará a melhor compreensão da fisiopatologia envolvida nestes casos bem como a melhores resultados cirúrgicos.

PALAVRAS-CHAVE: epilepsia, cirurgia, eletrodos subdurais, resultados, padrões.

Epilepsy Surgery Program, Hospital Brigadeiro and Clinica de Diagnóstico e Terapêutica das Epilepsias, Sao Paulo SP, Brazil. Aceite: 9-maio-2000.

Dr. Arthur Cukiert - Rua Dr. Alceu de Campos Rodrigues 247/121 - 04544-000 São Paulo SP - Brazil. 
The need for invasive monitoring in patients with refractory epilepsy has been greatly reduced by the introduction of new technologies such as PET, SPECT and MRI in the clinical practice ${ }^{1,2}$. On the other hand, 10 to $30 \%$ of the patients with refractory epilepsy have non-localizatory non-invasive preoperative work-up results ${ }^{3}$. They often have normal MRI or imaging studies showing multifocal potentially epileptogenic lesions.

The better understanding of the pathophysiology of the epilepsies led to a better classification of the epileptic syndromes. Despite the fact that intracranial electrodes have often been used in the preoperative investigation of epileptics over the last decades, the patterns for their distribution over the cortex have usually been defined according to the specific patient's needs ${ }^{4-6}$.

This paper reports on the paradigms for subdural electrodes implantation in patients with different refractory epileptic syndromes.

\section{METHOD}

Twenty-nine adult refractory epileptic patients were studied. Patients were divided into five different epileptic syndromes that represented the majority of the patients who needed invasive recordings: bitemporal (Group I; $n=16$ ), bi-frontal-mesial (Group II, $n=5$ ), hemispheric (Group III; $n=2$ ), anterior quadrant (Group IV; $\mathrm{n}=3$ ) and posterior quadrant (Group V; $\mathrm{n}=3$ ).

Group I patients had bilateral independent temporal lobe spiking, non-localizatory surface videoEEG monitoring, normal MRI or bilateral mesial temporal sclerosis. All patients were implanted bilaterally with 32-contacts subdural grids (Fig 1). Patients with bi-fronto-mesial syndromes (Group II) had normal MRI, interictal EEG showing secondary bilateral synchrony and non-localizatory surface ictal recordings; they were implanted bilaterally (Figs 2 and 3) with subdural grids covering both the frontal convexity (64 contacts; $8 \times 8$ ) and mesial surfaces (16 contacts; $8 \times 2$ ). Group III patients had widespread hemispheric interictal spiking and non-localizatory surface ictal recordings. MRI was normal or showed hemispheric atrophy; they were implanted with two grids covering the entire hemisphere (two 64-contacts grids or one 64 and one 32-contacts grids). Patients with anterior quadrant syndromes (Group IV) had interictal abnormalities prevailing over the anterior quadrant, non-localizatory surface ictal recordings, some electroclinical suggestion of epileptogenic zones anterior to the central sulcus and normal MRI. They were implanted with two grids: one 64-contacts (Fig 4) grid over the frontal and anterior temporal lobes with its posterior rows of electrodes over the rolandic area and a 16-contacts grid over the fronto-mesial surface. Group V patients had widespread interictal spiking, non-localizatory surface ictal recordings, some electroclinical suggestion of a posterior quadrant seizure onset and normal MRI or posterior quadrant atrophy; they were implanted (Figs 5 and 6) with two subdural grids: one 64-contacts grid over the temporo-parietal surface with its anterior rows of contacts over the rolandic area and a 16-contacts grid over the occipital convexity.

No patient received steroids during the procedure. All patients received prophylactic antibiotics during the whole period of invasive recording. All Groups II-V patients were submitted to cortical stimulation through the implanted subdural electrodes. All grids were implanted through large craniotomies under general anesthesia. The mean recording time was 7 days ( 2 to 15 ).

\section{RESULTS}

All patients tolerated well the procedure. There was no sign or symptom of intracranial hypertension except for headache in 22 patients. In all except one Group II patient, prolonged electrocorticographic monitoring using the described subdural cortical coverage patterns was able to define a focal area amenable for resection (Fig 7). The Group II patient in whom coverage was not adequate had a focus in the most anterior fronto-polar region, which was included in the resection but not adequately sampled, disclosing a regional (non-focal) ictal onset on chronic electrocorticography.

In all Groups II-V patients cortical stimulation was able to adequately map the rolandic and speach areas as necessary. 


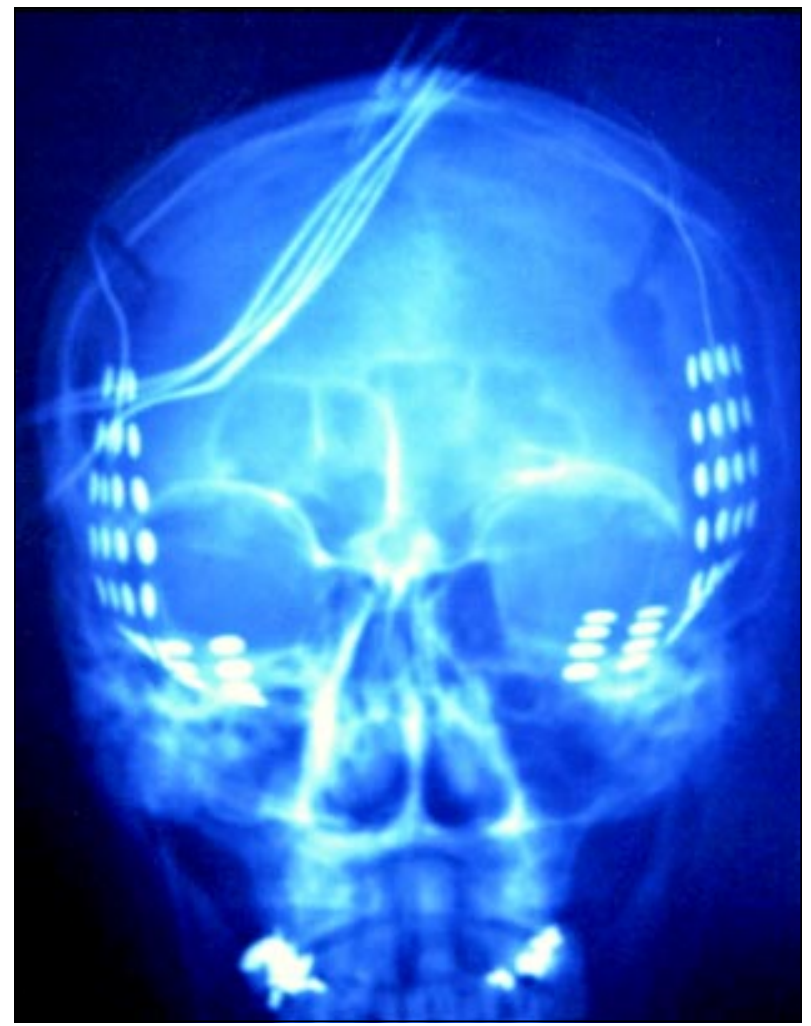

Fig 1. Skull X-ray showing the typical appearance of the bilaterally implanted grids in group I patients.

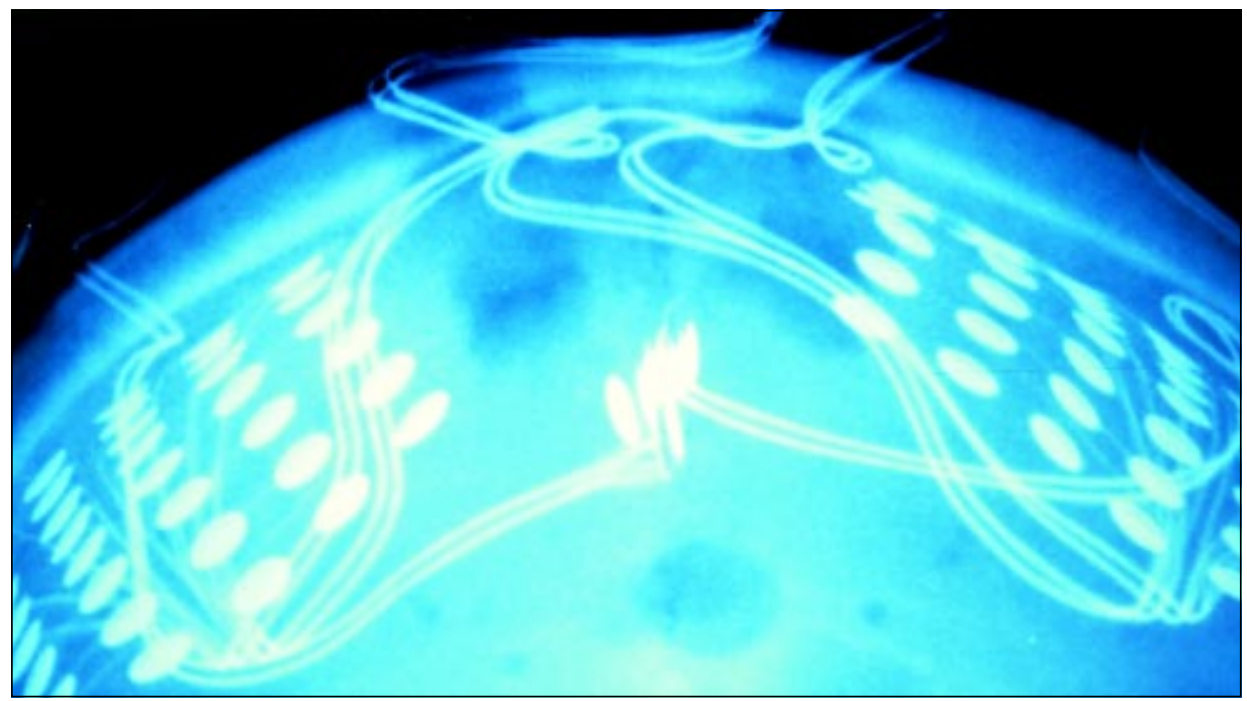

Fig 2. Skull X-ray showing the typical appearance of the bilaterally implanted grids in group II patients. 


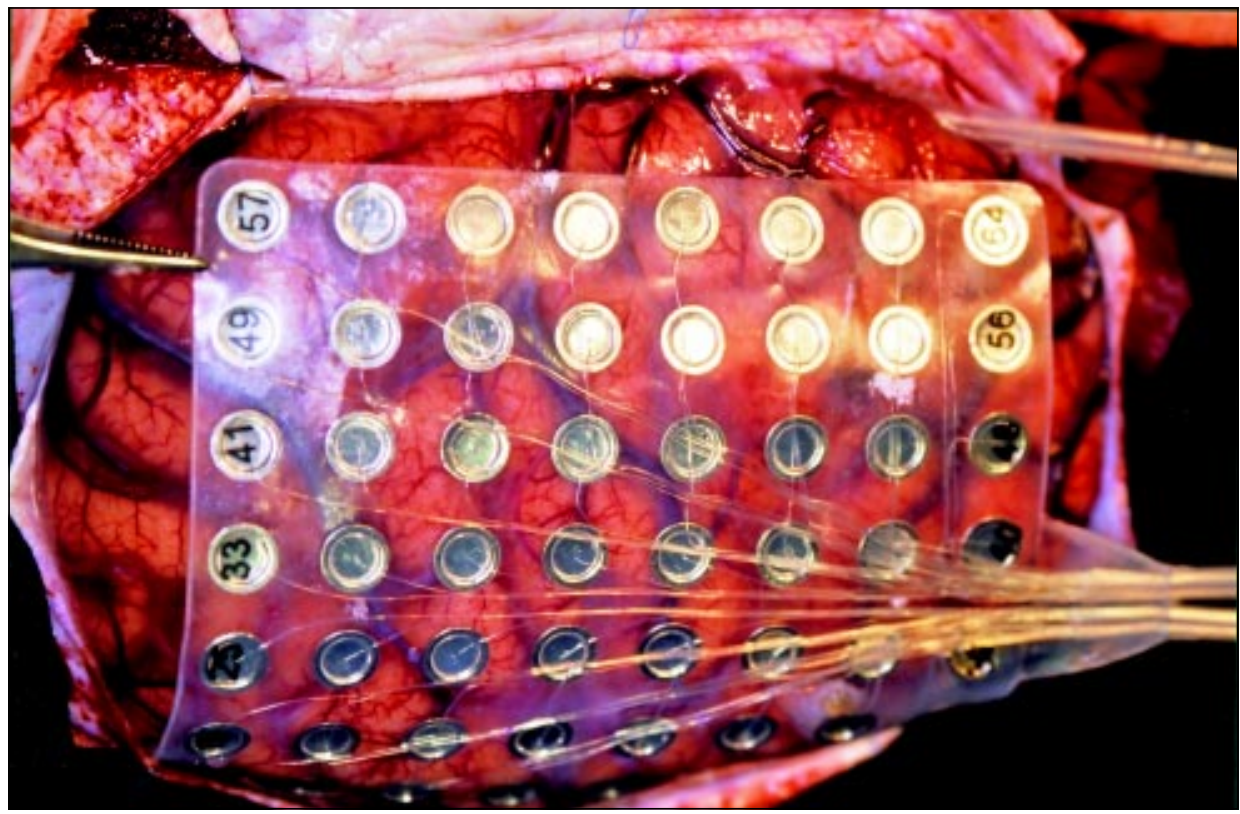

Fig 3. Intraoperative view of the right implanted hemisphere in a group II patient. A 64-contacts grid can be seen over the frontal convexity and the connecting cable from the mesial grid can be seen exiting the interhemispheric fissure.

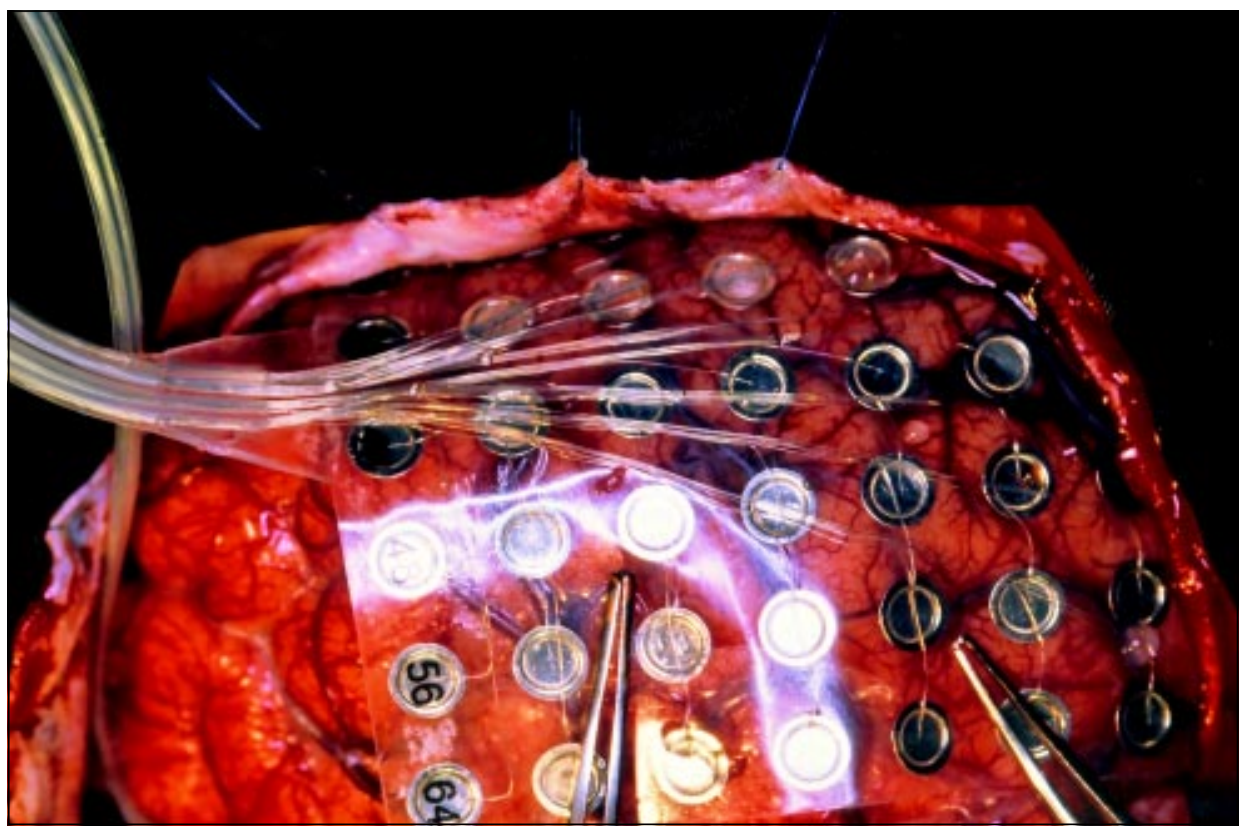

Fig 4. Intraoperative view of the right implanted hemisphere in a group IV patient. A 64-contacts grid can be seen over the frontal convexity with the rolandic region under the posterior rows of contacts. The connecting cable from the mesial grid can be seen exiting the interhemispheric fissure. 


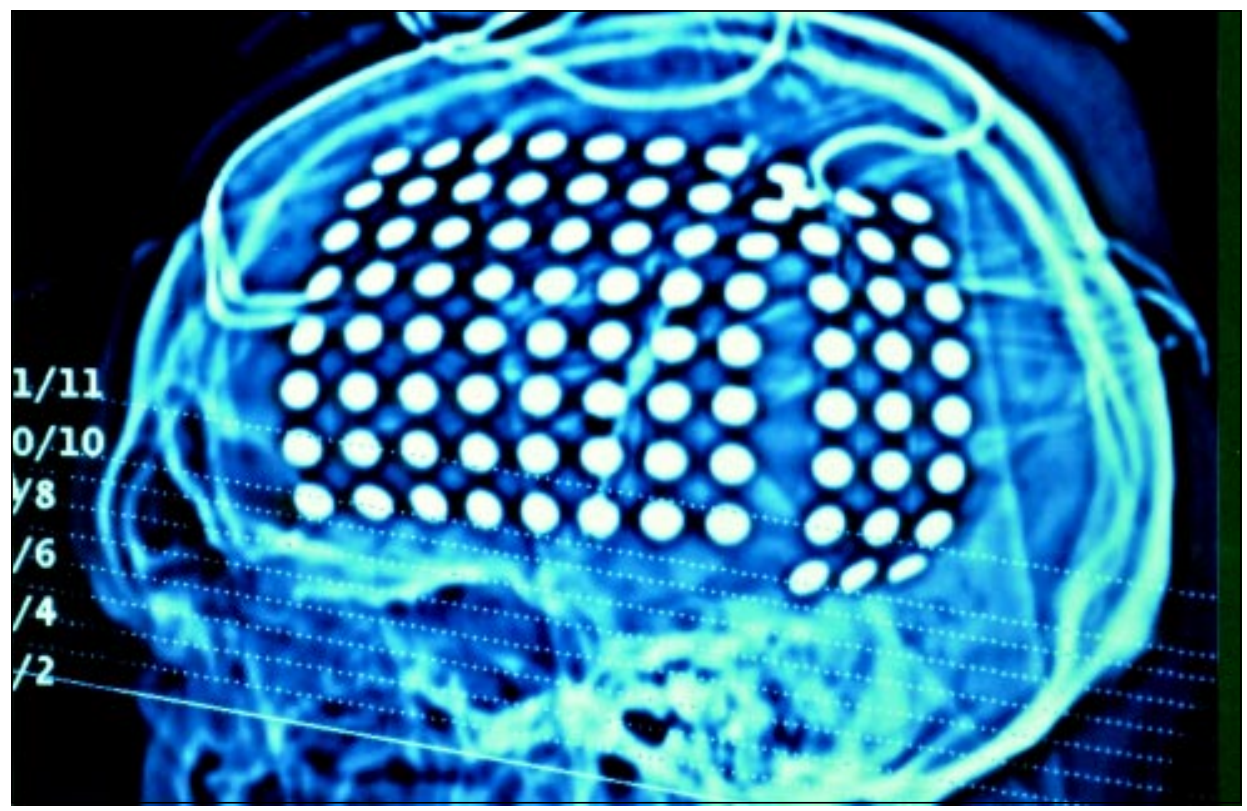

Fig 5. Skull x-ray showing the typical appearance of the implanted electrodes in group V patients.

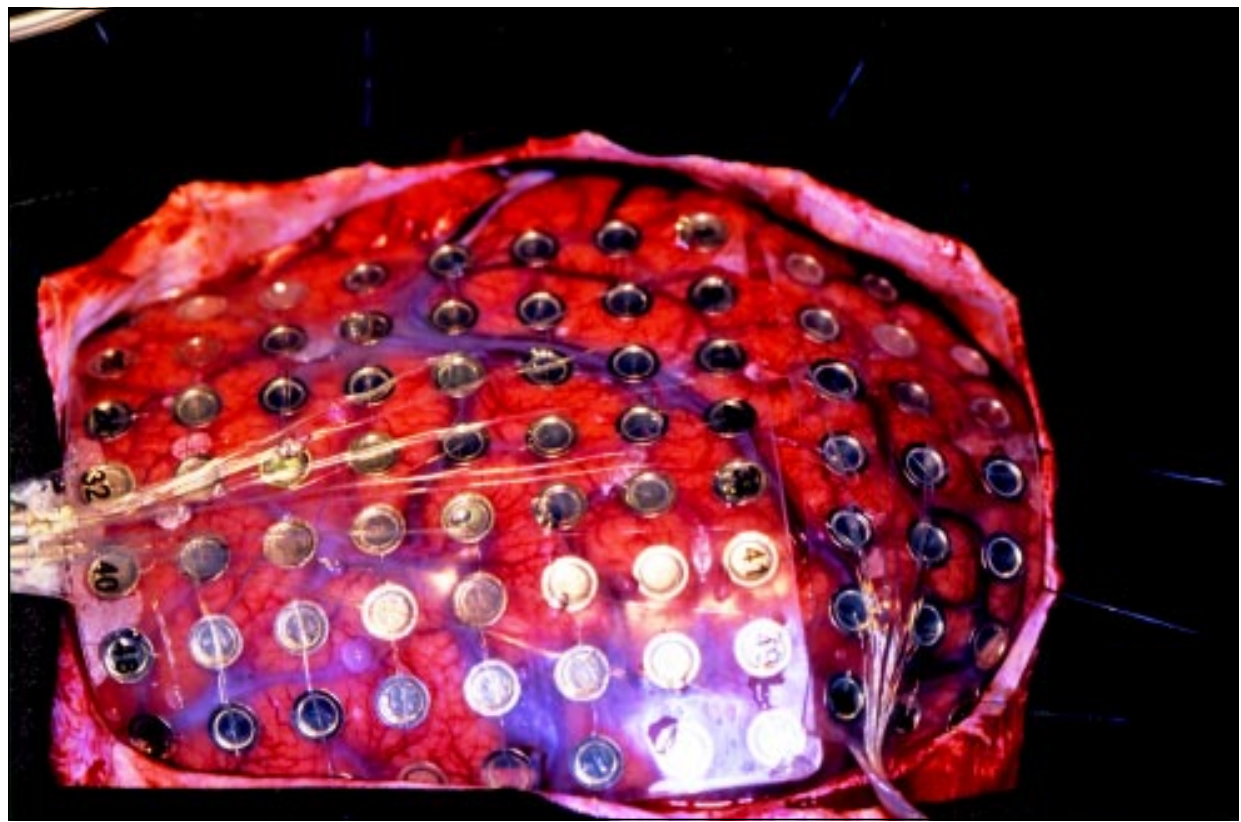

Fig 6. Intraoperative view of the 64- and 32 implanted grids in a group V patient. 


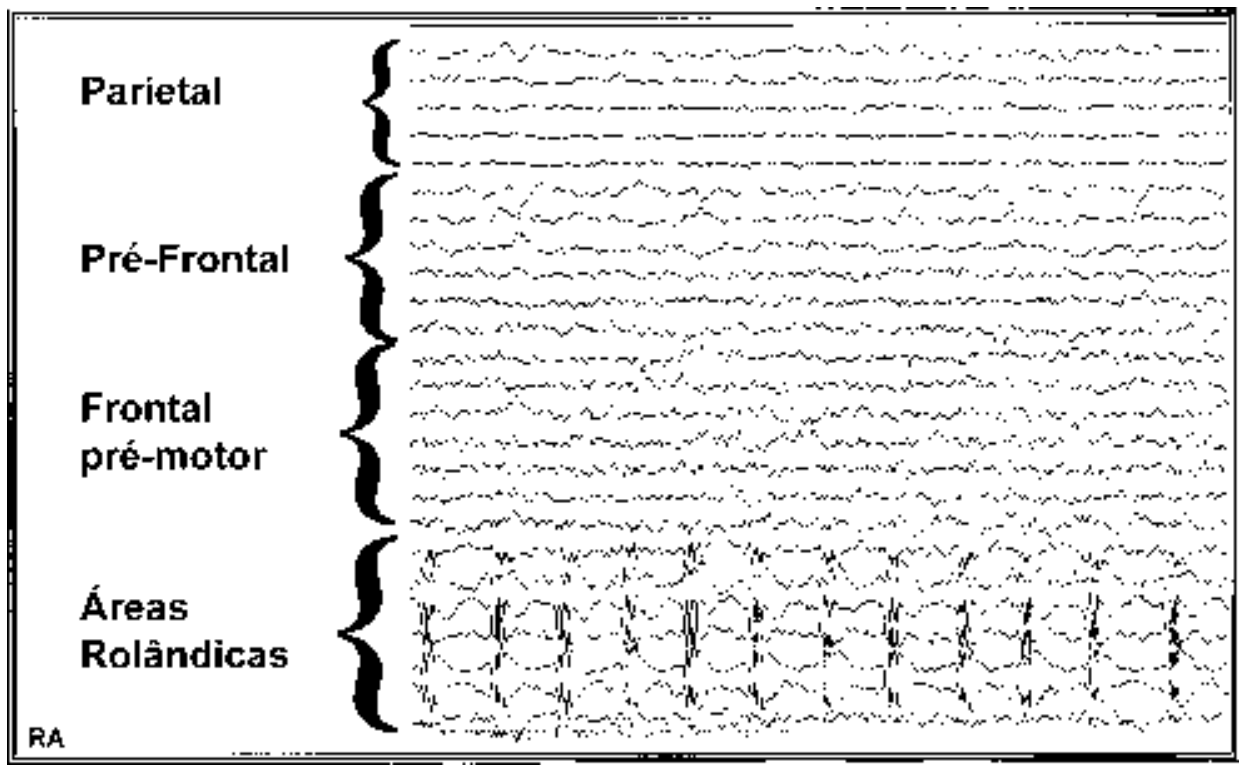

Fig 7. Sample of a seizure initiating at the rolandic areas in a group III patient. Areas rolândicas: rolandic areas.

\section{DISCUSSION}

Depth $^{7,8}$, epidural ${ }^{9}$, foramen ovale ${ }^{10}$ and subdural electrodes ${ }^{11-16}$ have been used in the workup of refractory epileptic patients with non-localizatory surface investigation. Subdural electrodes have been used in an increasing frequency over the last decade. Depth electrodes are inserted stereotactically in an orthogonal or posterior entry approaches. Subdural electrodes need a large craniotomy to be implanted but do not perforate the brain. Some centers have used subdural strips alone or in combination with other types of electrodes ${ }^{17,18}$. Subdural strips would provide only limited coverage in a patient population such as the one described in this paper and would probably lead to misdiagnosis.

Bilateral subdural grids' implantation may be needed. This is true mainly for patients with bilateral independent interictal temporal lobe spikinking and with secondary bilateral synchrony generated by the frontal lobes, as could be seen in Groups I and II.

Despite recent technological advances invasive neurophysiological studies are still necessary in some patients with refractory epilepsy. The better understanding of the pathophysiology of the epilepsies enabled us to divide patients into different syndromes which encompasses the majority of the refractory patients that needed subdural grids' implantation. The standardization of the paradigms for subdural implantation coupled to the study of homogeneous patients' populations as defined by MRI will certainly lead to a better understanding of the pathophysiology involved in such cases and an improved surgical outcome.

\section{REFERENCES}

1. Cendes F, Dubeau F, Andermann F, et al. Significance of mesial temporal atrophy in relation to intracranial ictal and interictal stereo-EEG abnormalities. Brain 1996;119:1317-1326.

2. Cascino GD, Trenerry MR, Sharbrough FW, So EL, Marsh WR, Strelow DC. Depth electrode studies in temporal lobe epilepsy: relation to quantitative resonance imaging and operative outcome. Epilepsia 1995;36:230-235.

3. Benbadis SR, So NK, Antar MA, Barnett GH, Morris HH. The value of PET scan (and MRI and Wada test) in patients with bitemporal epileptiform discharges. Arch Neurol 1995;52:1062-1068.

4. Behrens E, Zentner J, van Roost D, Hufnagel A, Elger CE, Schram J. Subdural and depth electrodes in the presurgical evaluation of epilepsy. Acta Neurochir (Wien) 1994;128:84-87. 
5. Jayakar P, Duchowny M, Resnick TJ. Subdural monitoring in the evaluation of children for epilepsy surgery. Child Neurol 1994;9(Suppl 2):61-66.

6. Adelson PD, Black PM, Madsen JR, et al.. Use of subdural grids and strip electrodes to identify a seizure focus in children. Pediatr Neurosurg 1995;22:174-180.

7. Binnie CD, Elwes RD, Polkey CE, Volans A. Utility of stereoelectroencefalography in preoperative assessment of temporal lobe epilepsy. J Neurol Neurosurg Psychiatry 1994;57:58-65.

8. Ross DA, Brunberg JA, Drury I, Henry TR. Intracerebral depth electrode monitoring in partial epilepsy: the morbidity and efficacy of placement using magnetic resonance image-guided stereotactic surgery. Neurosurgery 1996;39:327-333.

9. Awad IA, Assirati JA, Burgess R, Barnett GH, Luders H. A new class of electrodes of intermediate invasiveness: preliminary experience with epidural pegs and forame ovale electrodes in the mapping of seizure foci. Neurol Res 1991;13:177-183.

10. Wieser HG, Elger CE, Stodieck SR. The foramen ovale electrode: a new recording method for the preoperative evaluation of epileptics suffering from mesio-basal temporal lobe epilepsy. Electroencephalogr Clin Neurophysiol 1985;61:314-322.

11. Swartz BE, Rich JR, Dwan PS, et al.. The safety and efficacy of chronically implanted subdural electrodes: a prospective study. Surg Neurol 1996;46:87-93.

12. Smith JR, Flanigin HF, King DW, et al.. Analysis of a four-year experience with depth electrodes and a two-year experience with subdural electrodes in the evaluation of ablative seizure surgery candidates. Appl Neurophysiol 1987;50:380-385.

13. Luders H, Awad I, Burgess R, Wyllie E, vanNess P. Subdural electrodes in the presurgical evaluation for surgery of epilepsy. Epilepsy Res 1992; 5(Suppl):147-156.

14. Wyllie E, Luders H, Morris HH, et al.. Subdural electrodes in the evaluation for epilepsy surgery in children and adults. Neuropediatrics 1988;19:80-86.

15. Jennum P, Dhuna A, Davies K, Fiol M, Maxwell R. Outcome of resective surgery for intractable partial epilepsy guided by subdural electrode arrays. Acta Neurol Scand 1993;87:434-437.

16. Adelson PD, O'Rourke DK, Albright AL. Chronic invasive monitoring for identifying seizure foci in children. Neurosurg Clin N Am 1995;6:491-504.

17. Sperling MR, O'Connor MJ. Comparison of depth and subdural electrodes in recording temporal lobe seizures. Neurology 1989;39:1497-1504.

18. Blatt DR, Roper SN, Friedman WA. Invasive monitoring of limbic epilepsy using stereotactic depth and subdural strip electrodes: surgical technique. Surg Neurol 1997;48:74-79. 